\title{
Actions of Opioids on Primate Spinothalamic Tract Neurons
}

\author{
Wm. S. Willcockson, J. Kim, H. K. Shin, J. M. Chung, and W. D. Willis \\ Marine Biomedical Institute, and Department of Anatomy and Neurosciences, University of Texas Medical \\ Branch, Galveston, Texas 77550-2772
}

\begin{abstract}
The effects of iontophoretically applied opiates were tested on 24 spinothalamic tract cells in 12 anesthetized monkeys. The drugs used were chosen because of their agonist actions on different classes of opiate receptors $(\mu$, morphine; $\kappa$, dynorphin; $\delta$, methionine enkephalinamide; $\sigma, N$-allylnormetazocine or SKF 10047 and phencyclidine). The actions of the opiate drugs were generally inhibitory, although excitatory or mixed effects were sometimes seen, especially with morphine and dynorphin. Drug effects could change, depending on the position of the iontophoretic electrode array or on the current employed. Naloxone sometimes antagonized the action of the opiate drugs used, but naloxone did not seem to be a drug suited for iontophoretic application. A number of explanations are discussed to explain the variable actions of the opiate drugs.
\end{abstract}

The investigation of the effects of opioid substances on nociceptive neurons should help clarify the mechanisms by which these drugs cause analgesia. While the analgesia produced by systemically administered opiates involves supraspinal structures, there is also good evidence for an action at the spinal cord level (Yaksh, 1981). Endogenous opioids are present in the spinal cord and may be released by segmental circuits or by axons descending from the brain to modulate the transmission of nociceptive signals (Chung et al., 1983; Woolf et al., 1980; Yaksh and Elde, 1981; see reviews by Duggan and North, 1984; North, 1979; Willis, 1982; Zieglgänsberger, 1984).

A number of studies have been made of the effects of opioid substances on neurons in the dorsal horn of the spinal cord that are presumed to participate in somatosensory functions. When morphine is administered systemically, it has a predominantly inhibitory action on nociceptive dorsal horn neurons (Calvillo et al., 1979; Davies and Dray, 1978; Einspahr and Piercey, 1980; Jurna and Grossman, 1976; Kitahata et al., 1974; Le Bars et al., 1975, 1976; Zieglgänsberger and Bayerl, 1976; however, $c f$. Woolf and Fitzgerald, 1981). More variable effects have been noted when morphine is released in the vicinity of dorsal horn neurons by microiontophoresis. The most common response is inhibition, but, in addition, excitatory or biphasic effects, if any, are often reported (Belcher and Ryall, 1978; Calvillo et al., 1974, 1979; Davies and Dray, 1978; Dostrovsky and Pomeranz, 1973, 1976; Duggan et al., 1976, 1977a, 1981; Piercey et al., 1980; Sastry and Goh, 1983; Zieglgänsberger and Bayerl, 1976). Similarly, the effects of iontophoretically applied enkephalin may

\footnotetext{
Received Aug. 20, 1985; revised Jan. 20, 1986; accepted Feb. 20, 1986.

We thank Helen Willcockson for the illustrations, Griselda Gonzales for the histologic studies, Phyllis Waldrop for typing the manuscript, and Dr. Ken Johnson for gifts of phencyclidine and $N$-allylnormetazocine and for his helpful discussion of the manuscript.

This work was supported by NIH Research Grants NS 09743, NS 11255, NS 18830 , and NS 21266 .

Correspondence should be addressed to Dr. W. D. Willis, Marine Biomedical Institute, University of Texas Medical Branch, 200 University Boulevard, Galveston, TX 77550-2772.

Copyright (C) 1986 Society for Neuroscience $0270-6474 / 86 / 092509-12 \$ 02.00 / 0$
}

be inhibitory or excitatory, although the usual effect is inhibition (Davies and Dray, 1978; Duggan et al., 1977b, 1981; Randić and Miletić, 1978; Sastry and Goh, 1983; Satoh et al., 1979; Zieglgänsberger and Sutor, 1983; Zieglgänsberger and Tulloch, 1979).

Our laboratory has been investigating the transmission of nociceptive information by neurons belonging to the spinothalamic tract (STT) in the monkey and the modulation of that information by local spinal cord circuits and by pathways descending from the brain (Chung et al., 1979, 1984; Gerhart et al., 1981, 1984; Trcvino ct al., 1973; Willis ct al., 1974, 1977). The study of STT cells offers the advantage that the STT is likely to play an important role in signaling pain in humans, as well as in other primates (Noordenbos and Wall, 1976; Vierck and Luck, 1979; see review by Willis, 1985), and so changes in the activity of STT cells are of particular interest in the context of pain mechanisms.

We have in the past investigated the effects of different classes of drugs applied iontophoretically onto primate STT cells, including amino acids, monoamines, and several peptides (Jordan et al., 1978; Willcockson et al., 1984a, b). The only opioid substances tested were methionine and leucine enkephalin(Willcockson et al., 1984b), which produced a naloxone-reversible inhibition of STT cells. For the present investigation, we wished to examine the actions of other opioid substances. Since there are a number of different opiate receptors, as shown by physiological studies (Martin et al., 1976), binding experiments (Chang et al., 1980; Fields et al., 1980; Kosterlitz et al., 1980; Lord et al., 1977), and smooth muscle bioassays (Hutchinson et al., 1975; Lord et al., 1977; Wüster et al., 1980), we decided to try agents that appear to be agonists for each of several opiate receptor types. Morphine was used as an agonist for the $\mu$ receptor, dynorphin for the $\kappa$ receptor, methionine enkephalinamide for the $\delta$ receptor, and $N$-allylnormetazocine (SKF 10047) and phencyclidine for the $\sigma$ receptor (Chavkin et al., 1982; Huidoboro-Toro et al., 1981; Quirion et al., 1981; Zukin and Zukin, 1979, 1981; see also reviews by Martin, 1984; Zieglgänsberger, 1984).

A preliminary report of our findings has been made (Willcockson et al., 1985).

\section{Materials and Methods}

Experiments were conducted on 12 monkeys (Macaca fascicularis) weighing $2.0-3.5 \mathrm{~kg}$. The animals were anesthetized initially with a mixture of halothane, nitrous oxide, and oxygen. A $60 \mathrm{mg} / \mathrm{kg}$ intravenous bolus of $\alpha$-chloralose, supplemented during the course of the experiment with an infusion of sodium pentobarbital $(4 \mathrm{mg} / \mathrm{kg} / \mathrm{hr})$, was used to maintain anesthesia. Gallamine triethiodide was employed to paralyze the musculature, and the animal was artificially ventilated. End-tidal $\mathrm{CO}_{2}$ was maintained between 3.5 and $4.5 \%$. Rectal temperature was regulated near $37^{\circ} \mathrm{C}$.

Access to the lumbosacral spinal cord was provided by a laminectomy at vertebral levels L2 to L6 for recording from STT cells. Following craniotomy, a concentric bipolar steel electrode was lowered into the caudal portion of the ventral posterior lateral nucleus of the right thal- 


\begin{tabular}{|c|c|c|c|c|c|c|c|}
\hline Drug $^{a}$ & Excitation $^{b}$ & Inhibition & $\begin{array}{l}\text { No } \\
\text { effect }\end{array}$ & $\begin{array}{l}\text { Biphasic } \\
\text { effect }^{c}\end{array}$ & $\begin{array}{l}\text { Multiple } \\
\text { effect }^{d}\end{array}$ & Total & $(\mathrm{nA})$ \\
\hline \multicolumn{8}{|c|}{ Versus GLU activity } \\
\hline MOR & $3(120 \%)$ & $5(88 \%)$ & 1 & 3 & 7 & 19 & $7-100$ \\
\hline DYN & $2(236 \%)$ & $3(75 \%)$ & 0 & 2 & 6 & 13 & $15-50$ \\
\hline MKN & 0 & $2(83 \%)$ & 0 & 0 & 1 & 3 & $25-75$ \\
\hline PCP & 0 & $4(85 \%)$ & 0 & 1 & 3 & 8 & $7-50$ \\
\hline SKF & 0 & 1 & 0 & 1 & 1 & 3 & $7-25$ \\
\hline \multicolumn{8}{|c|}{ Versus pinch activity } \\
\hline MOR & $2(77 \%)$ & l (24\%) & 5 & 2 & 0 & 10 & $25-50$ \\
\hline DYN & 0 & $1(20 \%)$ & 1 & 1 & 0 & 3 & $50-75$ \\
\hline $\mathrm{MKN}$ & 0 & $3(82 \%)$ & 0 & 1 & 0 & 4 & $50-75$ \\
\hline $\mathbf{P C P}$ & 0 & $3(50 \%)$ & 0 & 0 & 0 & 3 & $10-50$ \\
\hline \multicolumn{8}{|c|}{ Versus $C$ fiber activity } \\
\hline MOR & $2(100 \%)$ & $2(35 \%)$ & 1 & 1 & 0 & 6 & $25-100$ \\
\hline DYN & 0 & 0 & 4 & 0 & 0 & 4 & - \\
\hline PCP & 0 & $3(100 \%)$ & 0 & 0 & 0 & 3 & $50-75$ \\
\hline
\end{tabular}

\footnotetext{
${ }^{a}$ Barrel concentrations for MOR, PCP, and SKF $=50 \mathrm{~mm}$, for $\mathrm{MKN}=12 \mathrm{~mm}$, and for DYN $=5 \mathrm{mM}$.

${ }^{b}$ The number of cells exhibiting a single type of response as indicated by heading. In parentheses, the maximum percentage of excitation (column 2) or inhibition (column 3).

' Biphasic effects include such actions as inhibition followed by excitation or vice versa.

${ }^{d}$ Any combination of single or biphasic effects seen with changes in dose, time or electrode position relative to the cell.
}

amus-VPL nucleus of Olszewski (1952). The location of the electrode was confirmed by recording potentials evoked by electrical stimulation of the left dorsal column and by mechanical stimulation of the left hindlimb. The thalamic electrode was then used to activate STT cells antidromically (Trevino et al., 1973). STT cells were classified by their responses to innocuous or noxious mechanical stimulation of their receptive fields (Chung et al., 1979). Low-threshold (LT) cells responded well to innocuous but poorly to noxious mechanical stimulation of the skin; wide dynamic range (WDR) cells responded to innocuous stimuli and to a greater degree to noxious stimuli; high-threshold (HT) cells were activated only by noxious stimuli.

Seven- or 8-barreled glass microelectrodes were utilized for iontophoretic drug application and for recording from STT cells. A lowimpedance ( $<2 \mathrm{M} \Omega$ measured at $1 \mathrm{kHz}$ ) carbon fiber in the center barrel of the array recorded extracellular activity (Anderson and Cushman, 1981).

Drug concentrations and $\mathrm{pH}$ were as follows: $\mathrm{L}$-monosodium-glutamate (GLU), $0.2 \mathrm{M}, \mathrm{pH} 8.5$; morphine sulfate (MOR), $50 \mathrm{~mm}, \mathrm{pH} 5$; naloxone hydrochloride (NLX), $50 \mathrm{mM}, \mathrm{pH} \mathrm{4.5}$; dynorphin A(1-13) fragment (DYN), $5 \mathrm{~mm}$, pH 5.5; v-Ala ${ }^{2}$-methionine enkephalinamide acetate salt (MKN), $12 \mathrm{mM}$, pH $5 ;( \pm) N$-allylnormetazocine (NAM), 50 $\mathrm{mM}, \mathrm{pH} 5$; phencyclidine hydrochloride (PCP), $50 \mathrm{~mm}, \mathrm{pH} 5$. All compounds were dissolved in sterile, deionized water $\left(\mathrm{dH}_{2} \mathrm{O}\right)$ except for DYN, which was made up in $20 \mathrm{~mm}$ acetic acid to attain a more acidic $\mathrm{pH}$. The drugs were made up just prior to filling the barrels. All drugs were applied iontophoretically with cationic current, except GLU, which was expelled with anionic current. Retaining currents were kept at 7 $n A$. Current neutralization via a $0.2 \mathrm{M} \mathrm{NaCl}$-filled balancing barrel was used during all drug applications.

The compounds were tested against the background activity of STT cells, GLU-evoked responses, activation by noxious mechanical stimuli (intermittent manual pinch or constant pinch with a small clip), or activity evoked by electrical stimulation of a nerve supplying the receptive field. GLU activation was achieved by pulsed release of GLU $(10-25 \mathrm{nA})$ for $5 \mathrm{sec}$ at $10 \mathrm{sec}$ intervals. Drugs tested against GLU were iontophoresed continuously, usually over a $40 \mathrm{sec}$ period.

Extracellular spikes triggered window discriminator pulses, which were used by a computer to compile peristimulus time histograms. Control responses were compared to responses during the application of a test drug. The percentage change was calculated as [(number of impulses during $40 \mathrm{sec}$ test period/number of impulses during the $40 \mathrm{sec}$ control period) -1$] \times 100 \%$. A greater than $20 \%$ change was considered significant, and individual cell response variability was considered.
Recording sites were marked by passing direct current through the carbon fiber. The sites were visible on histologic sections as microlesions.

\section{Results}

In all, 24 STT cells in 12 monkeys were tested for their responsiveness to iontophoretically applied opiate drugs. The STT cells were located in the dorsal horn at depths from the dorsal surface of the spinal cord ranging from 600 to $2000 \mu \mathrm{m}$. Nine of the STT cells were in superficial laminae, since they were at depths of $600-1300 \mu \mathrm{m}$; lesions made by passing current through the recording microelectrode indicated that at least 4 of the STT cells were in or near lamina I. Other STT cells were in deeper laminae of the dorsal horn. Fifteen of the cells were at depths of $1500-2000 \mu \mathrm{m}$, and 7 marked recording sites were in laminae IV-VI.

Threshold currents for activating the STT cells from the VPL nucleus of the thalamus ranged from 50 to $700 \mu \mathrm{A}$. Latencies of the antidromic action potentials were $3.0-11.6 \mathrm{msec}$, corresponding to axonal conduction velocities of $17-67 \mathrm{~m} / \mathrm{sec}$ (assuming a conduction distance of $200 \mathrm{~mm}$ ). The receptive field of each STT cell was confined to the foot ipsilateral to the cell. The cells were classified according to their responsiveness to mechanical stimulation of the receptive fields. Two STT cells were LT cells, 12 were WDR cells, and 10 were HT cells. The WDR cells were distributed evenly between superficial and deep laminae of the dorsal horn, whereas in this sample 8 of $10 \mathrm{HT}$ STT cells were at depths of $1700-2000 \mu \mathrm{m}$. Thus, in these experiments, most HT cells were in the deeper layers of the dorsal horn. No correlation was noted between drug effects and either cell classification or cell location.

GLU pulses were used to excite each of the STT cells. It was often necessary to make several tracks adjacent to a given STT cell in order to find the optimal site for GLU activation of the cell. Low thresholds for GLU excitation (at 5-20 nA) appeared to correlate with the amplitude of the antidromic spike, suggesting that it was necessary for the tip of the electrode array to be near the soma or proximal dendrites of the STT cell in order for GLU to have a strong action. 
A

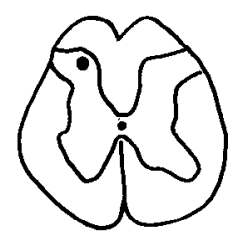

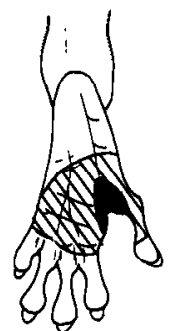

SALINE

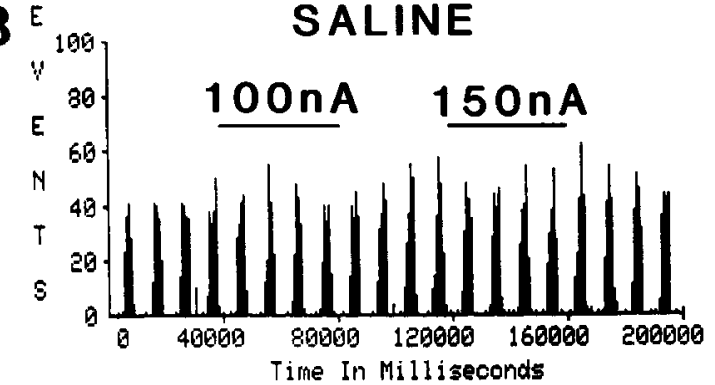

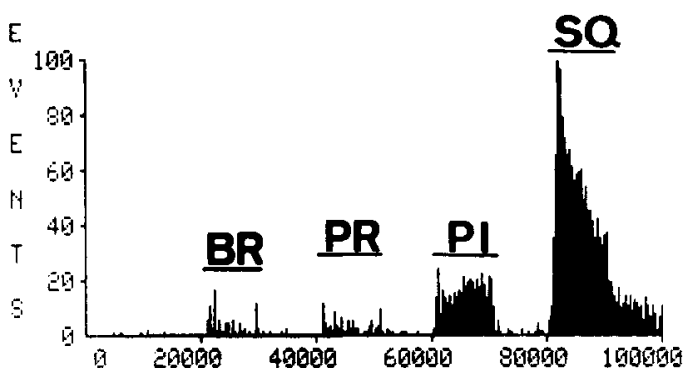

C

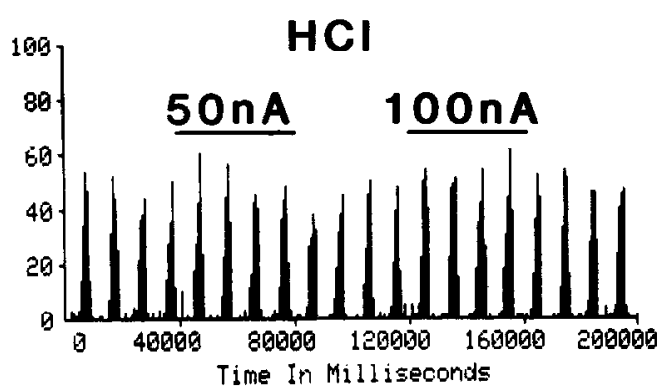

Figure 1. Lack of effect of iontophoretic currents applied through electrode barrels containing saline or HCl on a primate STT cell. A, Locations of the recording site and of the receptive field of an STT cell. Black region in the receptive field was the most sensitive area; hatched region had a higher threshold to mechanical stimulation. Histogram at right shows the responses of the cell to graded intensities of mechanical stimulation. $B R$, brush; $P R$, pressure; $P I$, pinch; $S Q$. squeeze. Single-pass peristimulus time histograms in $B$ and $C$ show a series of responses of the STT cell to pulses of GLU ( $25 \mathrm{nA})$. During the times indicated by the horizontal bars, the indicated currents were passed through the saline $(B)$ or $\mathrm{HCl}(C)$ barrel.

Opiate actions were tested primarily by interacting iontophoretically released opiate drugs with the responses of the STT cells to pulsed iontophoretic release of GLU. The reason for this was the assumption that a change in responsiveness to GLU would reflect a postsynaptic action of the opiate drug ( $c f$. Zieglgänsberger and Puil, 1973). In some cases, drug effects were also tested on the responses of STT cells to electrically evoked volleys in peripheral nerves or to natural forms of stimulation of the receptive fields. The effects of the various opiate drugs employed are summarized in Table 1 .

Before considering the actions of iontophoretically released opiate drugs on STT cells in detail, 2 control procedures will be described. The possibility that iontophoretic current per se might have an effect on the responses of STT cells to GLU pulses was tested by passing current through a saline-filled barrel. The fact that current alone had no effect in these experiments (due to the fact that current neutralization was used throughout) is illustrated by the cell whose responses are shown in Figure 1. The location of the STT cell and its receptive field are shown in Figure $1 A$, along with the responses to graded mechanical stimulation of the skin. The cell was judged to be a WDR cell, although the response to tactile stimulation was small. The single pass peristimulus time histogram in Figure $1 B$ shows that current passed through a saline barrel had no significant effect on the responses of the cell to pulses of GLU, even at the relatively high currents of 100 and $150 \mathrm{nA}$. Similar results were obtained for all 5 of the STT cells tested.

It is known that iontophoresis of drugs dissolved in solutions at low $\mathrm{pH}$ can result in the excitation of neurons due to the release of hydrogen ions, apart from any drug effects (Curtis, 1964). Therefore, another control procedure was done to determine the effect of hydrogen ions. Although none of the drugs used in this study was in a solution having a pH of less than 4.5 , we tested the effect of iontophoretic currents passed from an electrode barrel that contained an $\mathrm{HCl}$ solution having a $\mathrm{pH}$ of 3.5. In Figure $1 C$, it can be seen that an STT cell was unaf- fected by a current of $50 \mathrm{nA}$, but there may have been a slight excitation when the current was increased to $100 \mathrm{nA}$. Comparable experiments in which iontophoretic currents were passed using solutions of $\mathrm{HCl}$ at $\mathrm{pH} 3.5$ had no significant effect on 5 of 7 STT cells examined, but there was a slight excitation of the other 2 cells when the currents used were 100 to $150 \mathrm{nA}$.

\section{Effects of morphine on STT cells}

MOR released iontophoretically near 19 different STT cells had an effect on 18 . In most cases, the threshold current for MOR action ranged from 7 to $50 \mathrm{nA}$, but in 2 cases the threshold exceeded $100 \mathrm{nA}$.

The most common action of MOR on STT cells was inhibition, as demonstrated by a reduction in the sizes of the bursts of activity produced by pulses of GI.U. Inhibition of this kind was seen in recordings from 10 STT cells. The response of an STT cell could be reduced by as much as $98 \%$, although the reduction was usually in the range of $20-70 \%$ (for 7 cells). The inhibition was apparent within $20 \mathrm{sec}$ after the start of the MOR current ( 2 cycles of GLU pulses), but the duration of the MOR action varied. Sometimes the action of MOR was over within $10 \mathrm{sec}$ after the current was terminated, but in other instances, the action continued for as long as $4 \mathrm{~min}$. Usually ( 8 cells), recovery took $10-80 \mathrm{sec}$. Biphasic inhibitory actions were observed for 3 STT cells. These were characterized by a rapid onset of inhibition, with partial recovery within $20 \mathrm{sec}$ after termination of the MOR current, followed by a stronger inhibition (54-89\%) that lasted for as long as $2.5 \mathrm{~min}$.

An inhibitory action of MOR is shown in Figure 2 (same STT cell as illustrated in Fig. 1). In Figure $2 A$, MOR released with a current of $75 \mathrm{nA}$ is shown to reduce the response of the cell to pulses of GLU (15 nA) within $20 \mathrm{sec}$ of current application, and the inhibition lasted about a minute after the MOR current was terminated. The effect of MOR was also tested on the response of this cell to volleys in the $A$ and $C$ fibers of the tibial nerve (Fig. $2 B$ ). The current strength used was $100 \mathrm{nA}$, and it 

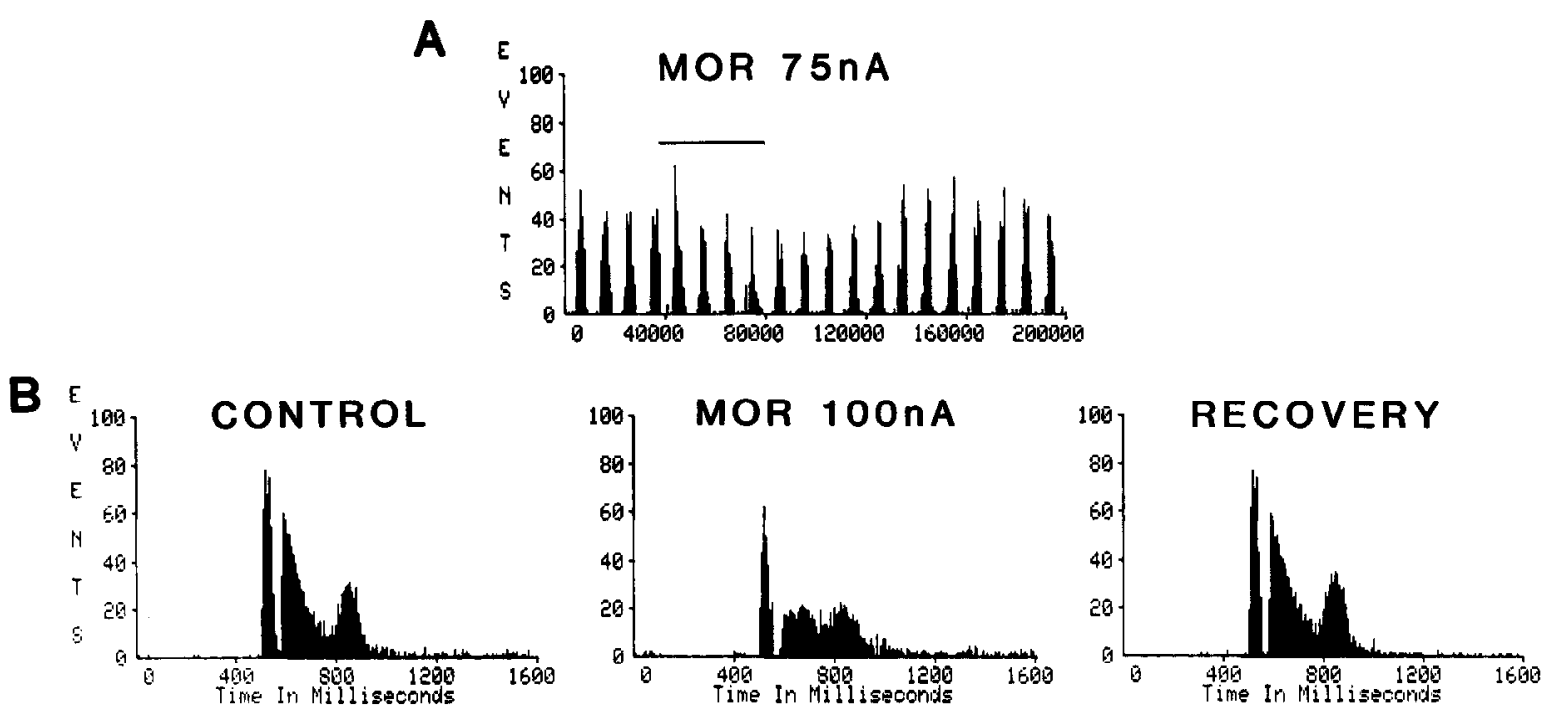

Figure 2. Inhibition of an STT cell by iontophoretic application of MOR. $A$, Effect of MOR (75 nA) in reducing the responses of the same STT cell as that illustrated in Figure 1 to pulses of GLU. B, Responses of the cell to stimulation of the tibial nerve at a strength suprathreshold for C fibers. Iontophoretic application of MOR, $100 \mathrm{nA}$ (middle record) reduced the response markedly, and there was recovery. Peristimulus time histograms in $B$ each represent the sum of 10 consecutive stimulus trials at a repetition rate of $1 / 2 \mathrm{sec}$.

can be seen from the poststimulus time histogram in the center of Figure $2 B$ that MOR was particularly effective in reducing the late components of the response. A similar inhibition of the responses of STT cells to afferent volleys in C fibers of a peripheral nerve was observed in 2 of the 6 neurons tested; there was a biphasic effect in 1 case and no effect in another (Table 1).

MOR had an excitatory action on 5 STT cells. The GLU responses were enhanced, often progressively, over a period of some $60 \mathrm{sec}$ (in 4 cells). The background activity of the cell could also be increased by MOR. Examples of the excitation of 2 STT cells are given in Figures 3 and 4.

Figure $3 A$ shows the location of the recording site, the receptive field, and the responses to graded strengths of mechanical stimulation. The STT neuron was classified as an HT cell. Figure $3 B$ shows the prolonged enhancement of the responses of the
Figure 3. Excitation of an STT cell by iontophoretic application of MOR. $A$, Receptive field, recording site, and responses of the cell to graded intensities of mechanical stimulation. MOR (25 and $50 \mathrm{nA}$ ) is seen to enhance the responses of the cell to GLU pulses (B) and background activity (MOR, $50 \mathrm{nA})(C)$. Iontophoretically applied naloxone (NLX, $50 \mathrm{nA}$ ) antagonized the action of MOR both during NLX application $(D)$ and $2.5 \mathrm{~min}$ afterwards $(E)$, but the effect of MOR recovered at least partially by $10 \mathrm{~min}$ (F).

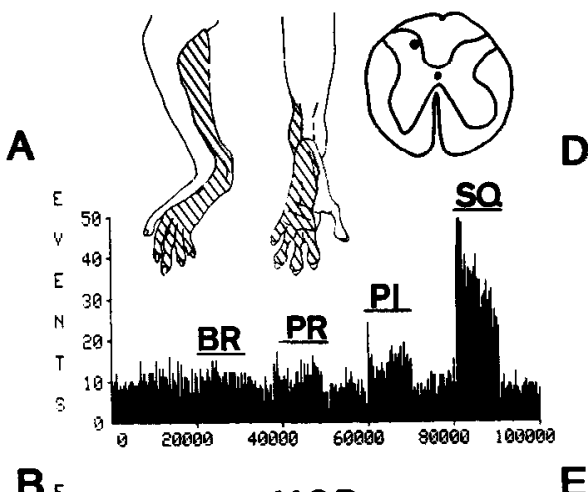

$\mathbf{B}_{\mathrm{E}}$
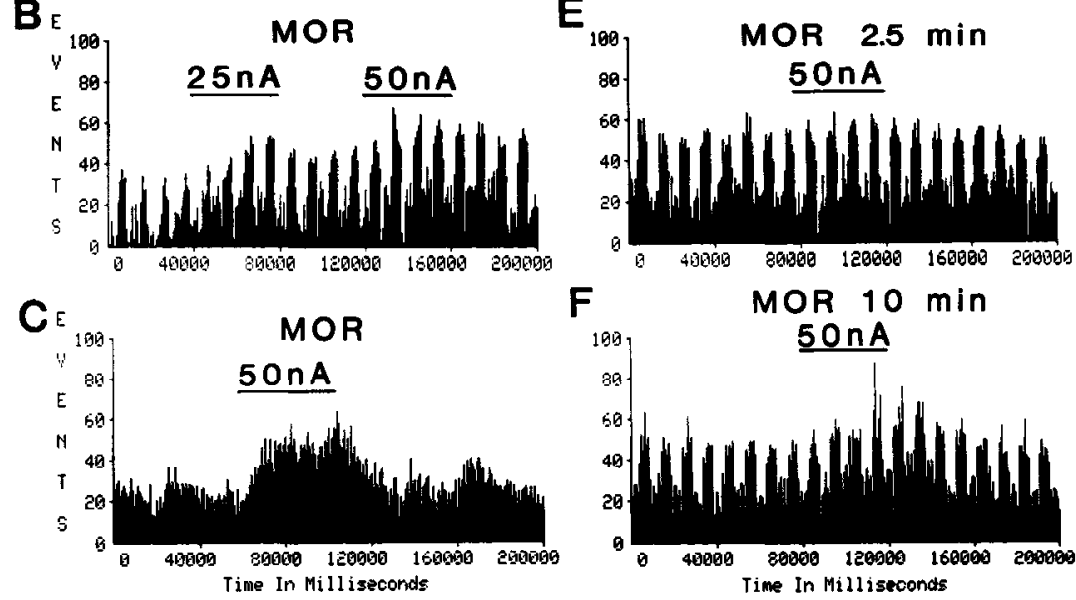
A
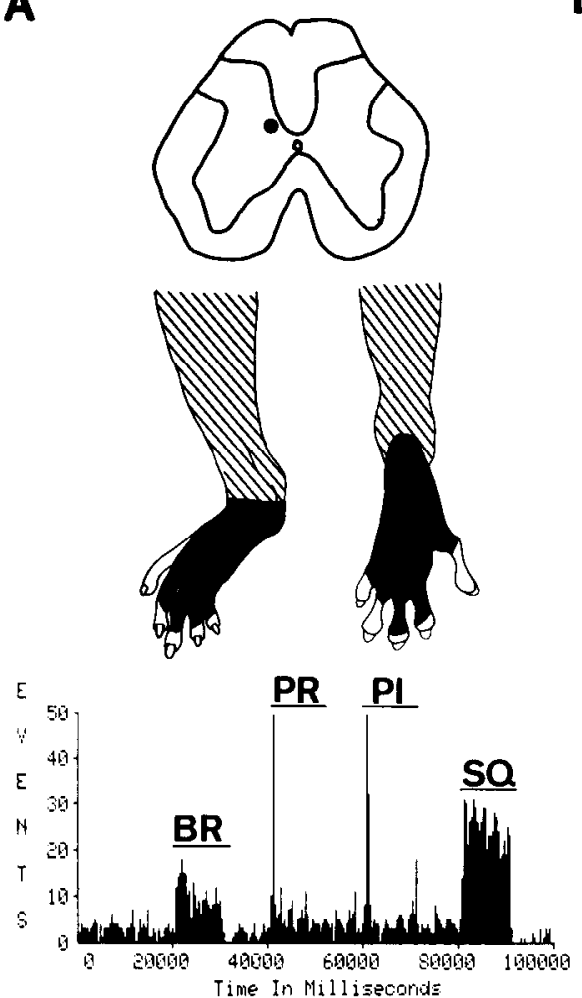

B

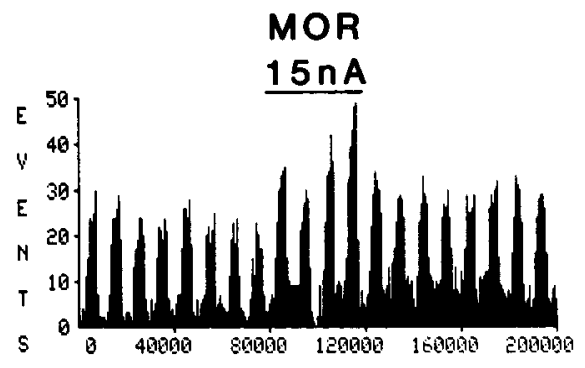

C

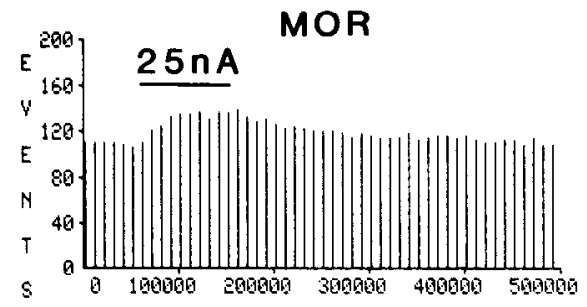

D

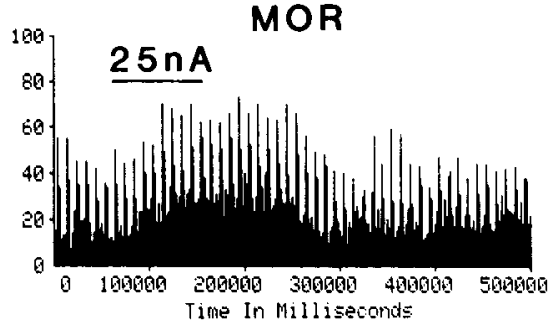

Figure 4. Excitation of another STT cell by MOR. $A$, Recording site, receptive field, and responses of an STT cell to graded intensities of mechanical stimulation. $B$, Responses of the cell to pulses of GLU were enhanced by iontophoretic application of MOR (15 nA). C, Vertical lines forming the histogram each represent the integral of the discharges produced by a volley in the $\mathrm{C}$ fibers of the tibial nerve. The responses to $\mathrm{C}$ fiber volleys were summed by computer. It can be seen that MOR (25 nA) enhanced the responses of this neuron to $C$ fiber volleys. $D$, Responses of the cell to a series of squeeze stimuli superimposed upon the background discharges of the cell. MOR ( $25 \mathrm{nA})$ enhanced both the background discharge rate and the responses to squeezing the skin. cell to GLU pulses that resulted from the iontophoretic release of MOR with currents of 25 and $50 \mathrm{nA}$. Note that the GLU responses had not fully recovered from the effects of MOR at $25 \mathrm{nA}$ before the higher dose was given. Note also that MOR enhanced the background activity of the cell, as well as its responses to GLU pulses. The effect of MOR on background activity alone is shown in Figure $3 C$.

Figure 4 shows the excitation of another STT cell by MOR. Figure $4 A$ shows the recording site, receptive field, and responses of the neuron to graded intensities of mechanical stimulation. The neuron was classified as a WDR cell. Figure $4 B$ shows the enhancement of the responses of the STT cell to GLU pulses produced by iontophoretic release of MOR (15 nA). The background activity was also increased during MOR application. When MOR was applied for a longer period of time, the change in background discharge rate was biphasic, with an initial enhancement followed by a reduction. Enhancement of the discharges produced by $C$ fiber volleys could also be demonstrated. The histogram in Figure $4 C$ consists of a series of $C$ fiber responses that were integrated and plotted as vertical lines (see Chung et al., 1984). The iontophoretic application of MOR (25 $\mathrm{nA}$ ) resulted in an increase in the sizes of the responses to the $\mathrm{C}$ fiber volleys. The responses of the same neuron to repeated squeeze stimuli are shown in Figure $4 D$. During MOR application $(25 \mathrm{nA})$, the responses were increased, as was the background activity. $C$ fiber responses were also enhanced in one other STT neuron of the 6 tested (Table 1).

Sequences of inhibition and excitation were produced by MOR in 9 cases. In 6 cells, inhibition was followed by excitation (for example, see Fig. $5 B$ ); in 2 cells, there was inhibition, excitation, and then inhibition; finally, in 1 cell there was excitation followed by inhibition.

In 7 of the 18 STT cells in which MOR had an effect, 2 or more of these patterns could be observed while recording from the same STT cell. The effect of MOR could be changed in many cases by altering the position of the microelectrode array with respect to the cell. Changing the vertical position of the electrode assembly did not seem to alter the qualitative effect of MOR. However, it was found that moving the electrode assembly in the horizontal plane resulted in a change in the pattern of response to MOR in 6 of 7 cells. In another 3 cells, the pattern of response changed when the amount of current applied through the MOR barrel was altered.

Figure 5 shows an example of an STT cell whose responses to MOR were altered by a shift of electrode position. The location of the cell, its receptive field, and its responses to graded mechanical stimulation of the skin are seen in Figure $5 A$. The cell was classified as a WDR neuron. With the electrode array in the initial position, there was a sequence of inhibition followed by excitation in response to 50 and $100 \mathrm{nA}$ of MOR (Fig. $5 B$ ). When the electrode was moved to an adjacent track, the release of MOR by 25 and $50 \mathrm{nA}$ of current produced just an inhibition (Fig. 5C), and this appeared to be somewhat stronger than the inhibition seen at the first position. When the electrode array was moved to still another location, inhibition followed by excitation was again observed (Fig. $5 D$ ).

In addition to its inhibitory and/or excitatory effects, as demonstrated by changes in the amplitudes of the responses to GLU pulses, MOR could affect the action potential generator of STT cells. One effect on action potential generation with high iontophoretic current strengths was a reduction in amplitude and an increased duration of both antidromic and synaptically driven spike potentials. This effect was seen both in STT cells that were inhibited and in cells that were excited by MOR. An important technical aspect of this finding was the necessity for careful monitoring to ensure that the spike potentials remained within the window of the window discriminator while histograms were being compiled during iontophoretic application of MOR. A second effect of MOR in some neurons was the triggering of burst discharges during MOR application. This effect often considerably outlasted the duration of MOR release.

The STT cells did not appear to become tolerant to the effects 
A

Figure 5. Changes in the action of MOR on an STT cell depending upon the position of the iontophoretic electrode assembly in relation to the cell. $A$, Location of the recording site, receptive field, and responses of the cell to graded intensities of mechanical stimulation. $B-D$, Different patterns of effects of iontophoretically applied MOR on the cell produced with the electrode array in 3 different positions with respect to the cell.
B
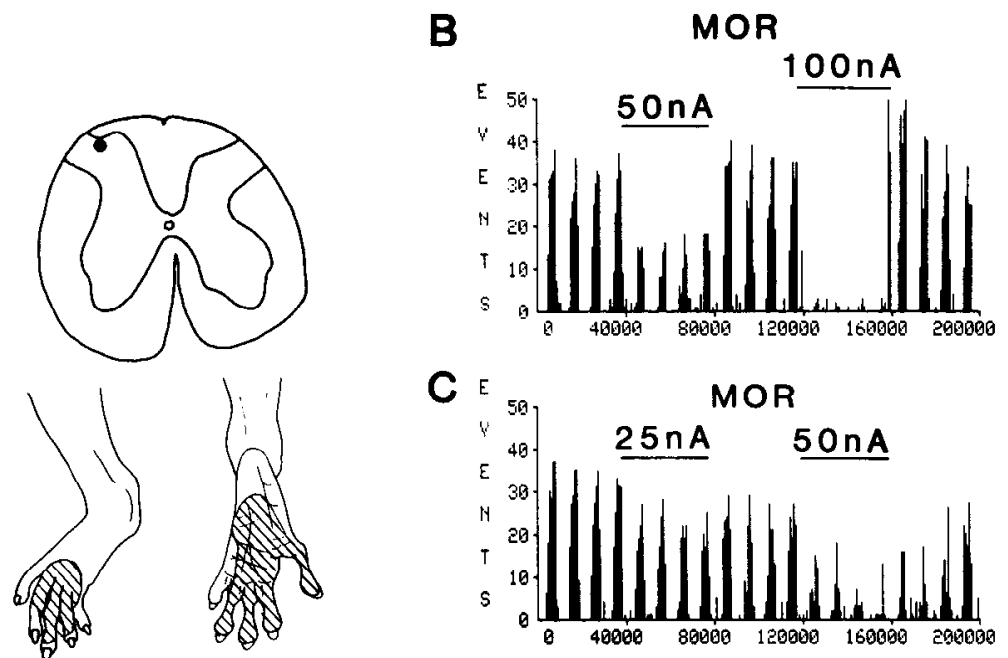

C
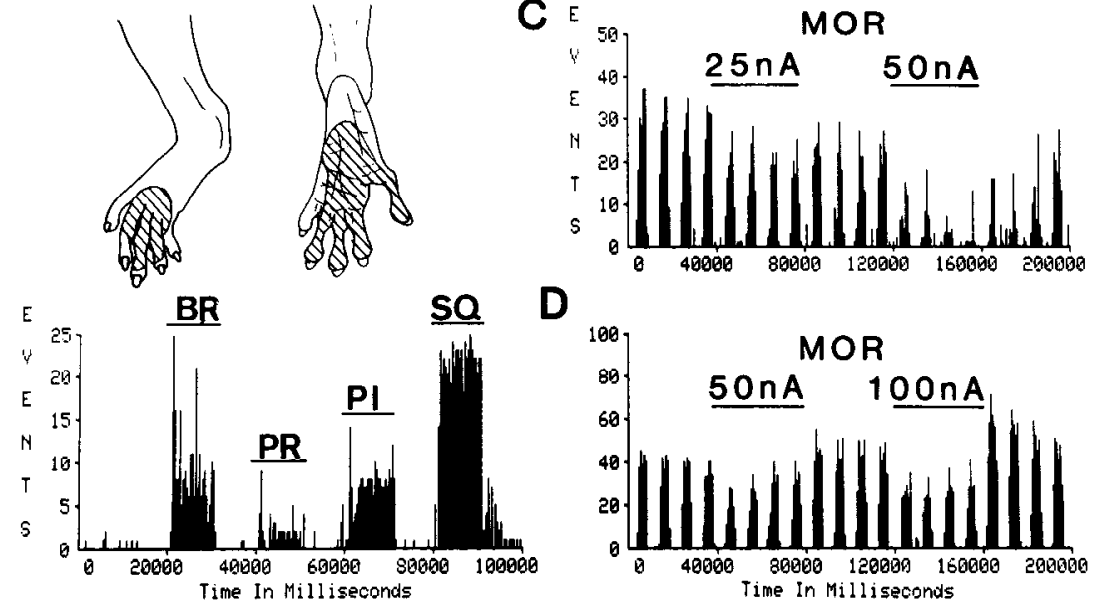

of MOR. In only 2 cells was MOR inhibition reduced after serial applications. In 6 cells a cumulative reduction of GLU-evoked activity occurred after repeated MOR iontophoresis, despite allowing $15-30 \mathrm{~min}$ for recovery and vertical repositioning to maximize the GLU response.

\section{Action of naloxone}

Naloxone (NLX) released iontophoretically with a sufficiently strong current had an agonistic action on STT cells. The effects of NLX were tested on 15 STT cells, and there was a significant action on 14 of thesc. Thresholds for effects ranged from 15 to $50 \mathrm{nA}$. The most common effect of NLX on the discharges evoked by pulses of GLU was an inhibition (up to $85 \%$ ). This was seen in 12 cases. Other actions included inhibition followed by excitation ( 2 cells), excitation ( 3 cells), and excitation followed by inhibition ( 1 cell). In several instances different actions were seen when NLX was applied from 2 or more electrode positions (this was seen in 4 of 7 cells in which this was examined). In another case, NLX had different effects when the current was low (excitation) than when it was high (inhibition). NLX effects could also be demonstrated by using the responses to noxious stimuli or to peripheral nerve volleys as a test. These NLX actions were mostly inhibitory.

An attempt was made to determine if iontophoretically applied NLX could antagonize the actions of MOR. Since NLX could have an action of its own, the current strength used to release NLX had to be reduced to the point that NLX itself had little or no action on the responses to GLU pulses. NLX was released before MOR application was begun, and then both drugs were released together. NLX appeared to antagonize the inhibition produced by MOR in 4 of 7 cells. However, it was possible to demonstrate recovery of the MOR action in only 1 case. NLX appeared to antagonize the excitatory effects of MOR on 2 STT cells (all cases tested). Partial recovery was seen within about 10-15 min.

An example of the antagonism of the excitatory action of MOR by NLX is shown in Figure 3. The excitation produced by MOR alone is shown by the increased sizes of the responses to GLU pulses in Figure $3 B$. In Figure $3 D$, NLX alone had little effect, but it reduced the excitation expected from MOR. When MOR was applied again after $2.5 \mathrm{~min}$, it had almost no effect, as shown in Figure $3 E$. By $10 \mathrm{~min}$ after NLX application, MOR again had some excitatory action, as scen in Figure $3 F$, indicating partial recovery.

\section{Effects of dynorphin}

The action of DYN was evaluated on 13 STT cells. DYN affected the activity of all of these cells at thresholds between 15 and $50 \mathrm{nA}$. The predominant effect was inhibition (9 cells). GLU-evoked responses could be inhibited by as much as $98 \%$ during iontophoretic application of DYN. Inhibition began within 10-40 sec, but maximum inhibition was sometimes delayed to as long as $3 \mathrm{~min}$. Recovery after termination of DYN application required from $40 \mathrm{sec}$ to $5 \mathrm{~min}$.

An example of a neuron whose responses to GLU pulses were inhibited by DYN is illustrated in Figure 6. The recording site, receptive field, and responses to graded strengths of mechanical stimulation are shown in Figure $6 A$. The cell was an HT neuron. The action of MOR (60 $\mathrm{nA})$ is shown in Figure $6 B$. There was a transient enhancement of the GLU response, followed by a long-lasting inhibition. DYN was then applied, with the effects shown in Figure $6, D-F$. A current of $25 \mathrm{nA}$ produced only a small reduction in the GLU responses (9\%), but $50 \mathrm{nA}$ caused a slowly developing and prolonged inhibition. The peak inhibition $(91 \%)$ had not been reached by the end of the histogram collection period (Fig. 6D), and so 2 additional histograms (Fig. $6, E, F$ ) were compiled to show the very long time course of recovery of the responses of this cell to GLU pulses.

In 3 cases, the effects of DYN were tested on the responses of STT cells to noxious mechanical stimuli. The responses of 2 cells were inhibited; in the third there was no effect. The responses to volleys evoked by electrical stimulation of a peripheral nerve were unaffected by DYN in the 4 cases examined.

An excitatory action of DYN was observed in 4 cases. The 

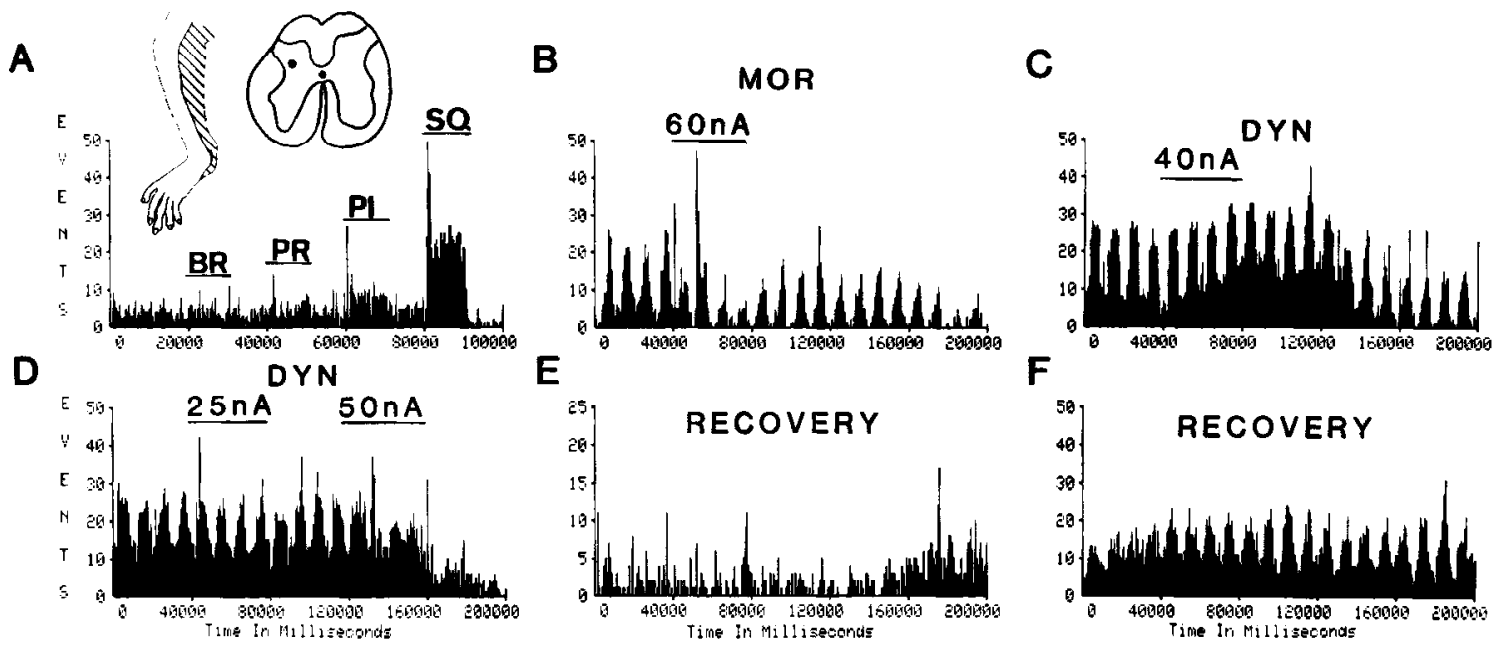

Figure 6. Effects of MOR and DYN on an STT cell. A, Receptive field, recording position, and responses of the cell to graded intensities of mechanical stimulation. Inhibitory effect of MOR $(60 \mathrm{nA})$ on the responses of the cell to GLU pulses is shown in $B$ and of DYN (25 and $50 \mathrm{nA})$ in $D-F$. When the electrode assembly was moved to a different position with respect to the cell, DYN (40 nA) now had a diphasic excitatory and then inhibitory action, as shown by changes in the responses of the cell to GLU pulses $(C)$.

maximum excitation occurred within 30 to $60 \mathrm{sec}$, and recovery required $30 \mathrm{sec}$ to $3 \mathrm{~min}$. An example of an excitatory action of DYN is given in Figure 7. The location of the recording site, receptive field, and responses of the STT cell to graded strengths of mechanical stimulation are shown in Figure $7 A$. The cell was classified as an HT neuron. Iontophoretic application of DYN $(15 \mathrm{nA})$ resulted in a slowly developing excitation, as shown in Figure $7 B$.

Responses to iontophoretic application of DYN other than pure inhibition were also seen. In some cases, there were mixed effects. For example, inhibition followed by excitation occurred in 4 cells. A sequence of inhibition, excitation, and then inhibition was observed in 1 case. Excitation followed by inhibition was found in 3 instances.
DYN had different actions on 6 STT cells depending on the position of the electrode array (2 cases) or on the strength of the DYN current (all 6 cells). For instance, in the case of the STT cell whose responses are shown in Figure 6, moving the electrode assembly to a different location changed the response to DYN from inhibition to excitation followed by inhibition (cf. Fig. 6, $D$ with $C$ ). For the STT cell whose responses are shown in Figure 7, raising the DYN current from 15 to $75 \mathrm{nA}$ converted the excitatory response to a sequence of inhibition followed by excitation ( $c f$. Fig. $7, B$ with $C$.).

Although MOR and DYN sometimes had similar effects, this was not the usual finding. Comparable effects were seen at a given electrode position for the 2 opiates in only 3 of 10 cases tested. In fact, both similar and different effects could be ob-
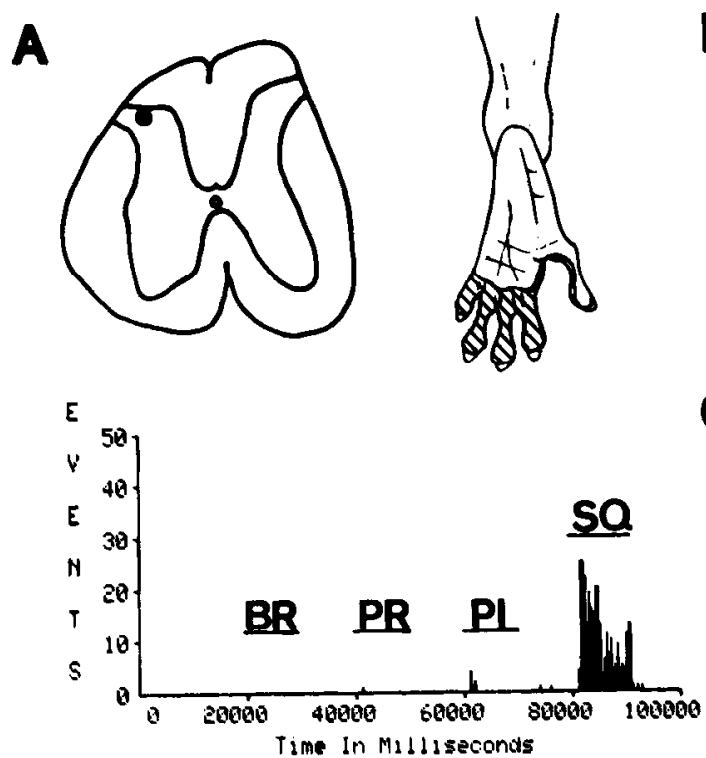

B

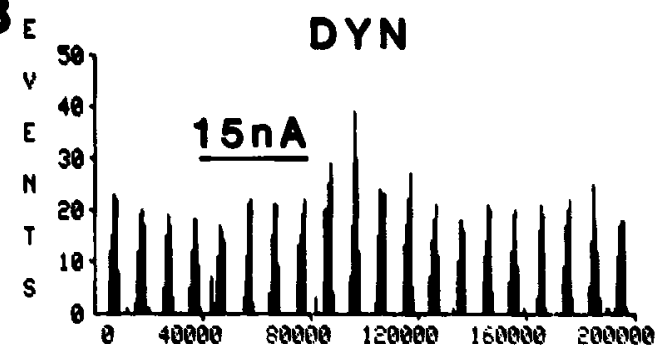

C

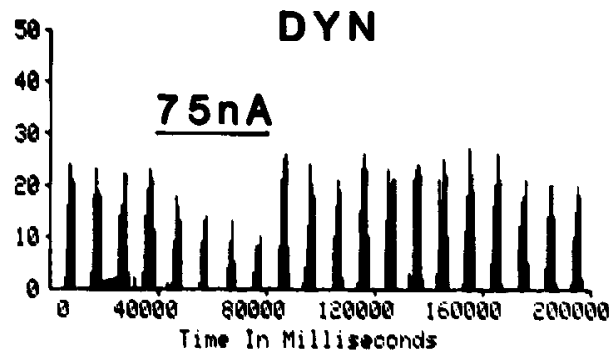

Figure 7. Current-dependent effects of DYN on an STI cell. $A$, Locations of the recording site and of the receptive field, as well as the responses of the cell to graded intensities of mechanicial stimulation. $B$, Enhancement of the responses of the cell to GLU pulses that was produced by iontophoretic application of DYN (15 nA). C, Excitation was converted to an inhibition followed by excitation, however, when the DYN current was increased (to $75 \mathrm{nA}$ ). 
A

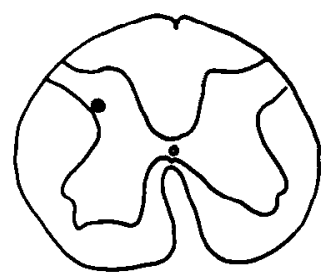

B

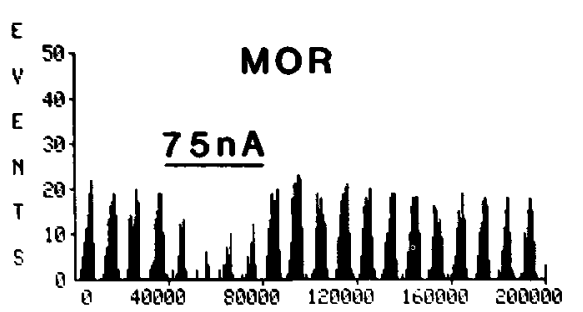

D
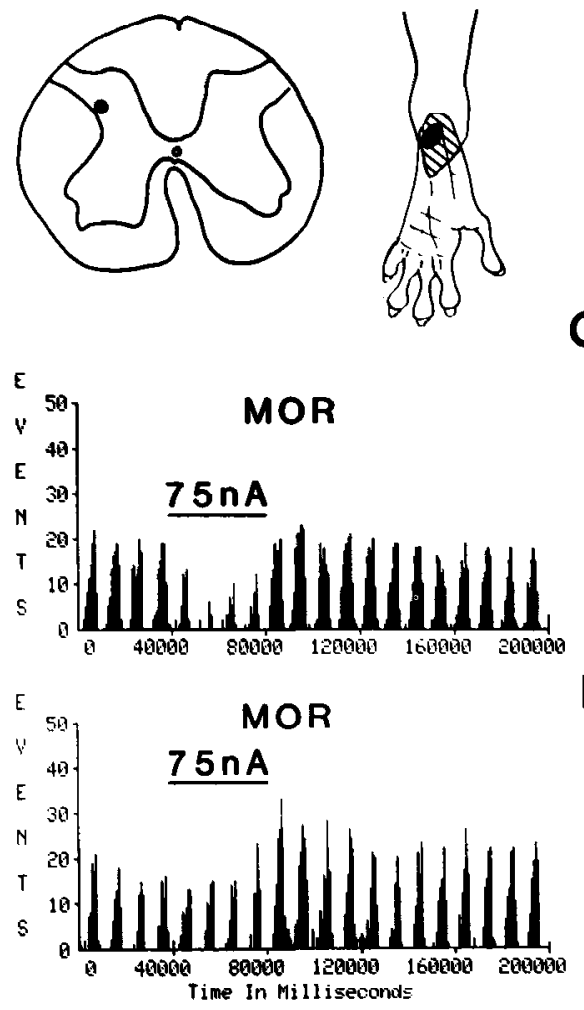

Figure 8. Effects of MOR and DYN applied iontophoretically at 2 different positions of the iontophoretic electrode array. $A$, Recording site, receptive field, and responses of the cell to graded intensities of mechanical stimulation. Also shown are changes in the responses of the cell to pulses of GLU due to release of MOR (75 $\mathrm{nA}, B)$ or DYN $(50 \mathrm{nA}, C)$ at one recording site. MOR had an inhibitory followed by an excitatory action and DYN an excitatory one. $D$ and $E$, Effects of the same agents when released at a different recording site. Now both substances produced a delayed excitatory action.

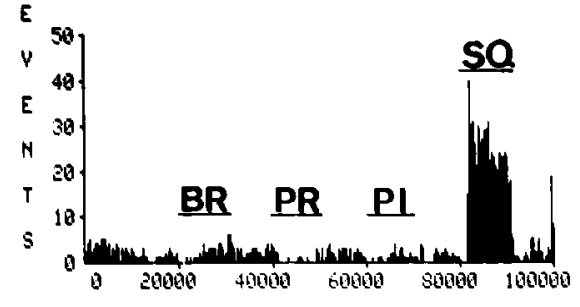

C

DYN

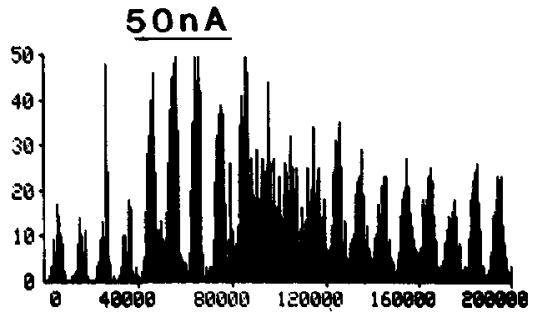

E

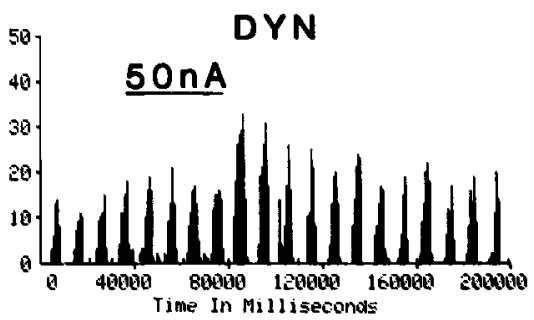

served for MOR and DYN released near a given STT cell, depending upon electrode position. For example, as shown in Figure 8, MOR and DYN had quite different actions when the electrode array was in one position, but similar actions when the electrode was moved to a different position. Figure $8 A$ shows the recording site, receptive field, and responses of the cell to graded intensities of mechanical stimulation. The cell was classified as an HT neuron. With the electrode assembly in one position, MOR applied iontophoretically (75 $\mathrm{nA})$ caused an initial inhibition of the cell, followed by excitation (Fig. 8B). By contrast, DYN (50 nA) produced a powcrful and long-lasting excitation (Fig. 8C). When the electrode array was moved to a position in a parallel track, both MOR and DYN produced a delayed excitation (Fig. 8, $D, E$ ).

Antidromic and orthodromic action potentials could be reduced in size and broadened by DYN in much the same fashion as by MOR. This change in spike configuration was seen whether DYN produced a decrease or an increase in the responses of the cell to GLU pulses or in background activity. DYN also caused bursting activity that outlasted the current application in 8 of 13 cells. A tolerancelike reduction in DYN effects was observed in only 1 cell. A cumulative inhibition of GLU responses after serial DYN application was seen in 4 of 13 cells observed.

The possible effect of NLX in antagonizing DYN inhibition of the responses of STT cells to GLU pulses was tested on only 2 cells. No effect of NLX was noted.

\section{Action of methionine enkephalinamide}

The iontophoretic release of MKN reduced the responses of STT cells to GLU pulses in all 3 cases examined. Thresholds ranged from 25 to $75 \mathrm{nA}$. Maximum inhibition was seen within 20 to $80 \mathrm{sec}$ after the MKN current was begun and full recovery occurred. In 1 case, there was a purely inhibitory action at one electrode position, but a sequence of inhibition followed by excitation when the electrode assembly was moved to another position.
An example of the inhibition of an STT cell by iontophoretic application of MKN is illustrated in Figure 9. The recording site, receptive field, and responses to graded intensities of mechanical stimulation are shown in Figure $9 A$. The cell was classified as a WDR neuron. MKN (75 $\mathrm{nA})$ caused a substantial inhibition of the responses of the cell to GLU pulses, and the inhibition outlasted the period of drug application by more than $2 \mathrm{~min}$

MKN inhibited the responses of the 2 cells tested to noxious mechanical stimulation, and it produced more of a reduction in the responses of 1 cell to volleys in $A \delta$ and $C$ fibcrs than to volleys in $A \alpha \beta$ fibers following electrical stimulation of a peripheral nerve. The effect of MKN on the responses of an STT cell to repeated squeezing of the skin with forceps is shown in Figure $9 D$. Note the similarity in the time course of the inhibition of the responses to pinching and of the responses to GLU pulses ( $c f$. Fig. $9, D$ with $B$ ).

The ability of iontophoretically applied NLX to antagonize the inhibition produced by MKN was tested on only 2 cells. There appeared to be some antagonism in 1 case, but recovery was not observed. NLX had no effect on the inhibition produced by $\mathrm{MKN}$ in the other case.

MKN reduced the action potentials of 1 STT cell. However, this action appeared to be weaker than was seen when MOR or DYN were tested. There was no obvious development of tolerance of the cells to MKN's effect after repeated application.

\section{Effects of phencyclidine and SKF 10047}

The action of the $\sigma$ receptor agonists PCP and NAM was generally inhibitory. PCP inhibited all 8 cells that were tested, and the inhibition was strong (up to $99 \%$ ). Thresholds ranged from 7 to $50 \mathrm{nA}$. The inhibition outlasted the period of current application by 10 to $40 \mathrm{sec}$. An example of the inhibitory effect of PCP is shown in Figure $9 C$. The inhibition increased with increasing dose ( 7 vs $15 \mathrm{nA}$ ).

PCP inhibited not only the responses of STT cells to GLU pulses, but also the responses to noxious mechanical stimuli. 
A

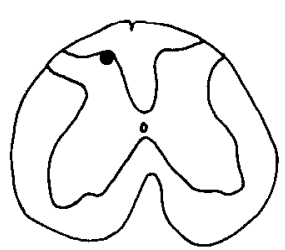

B E

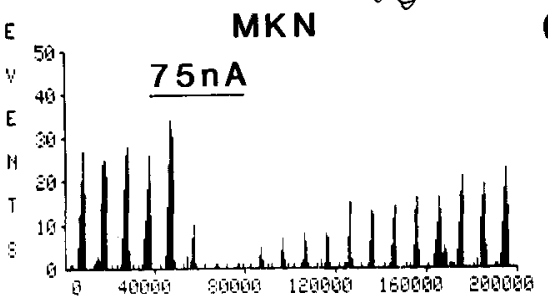

D

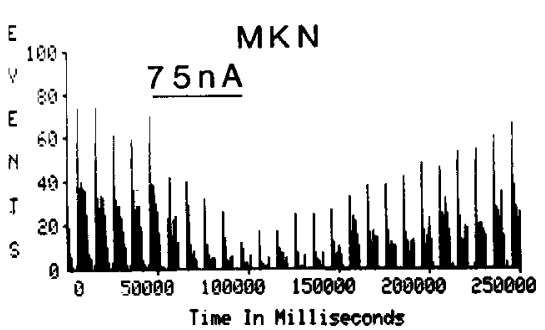

E

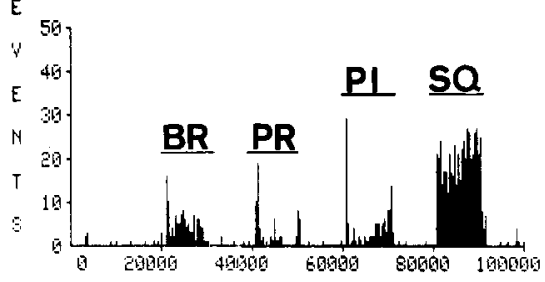

C

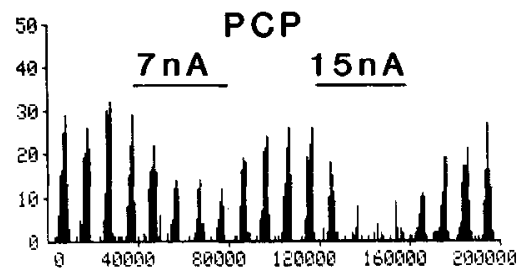

E

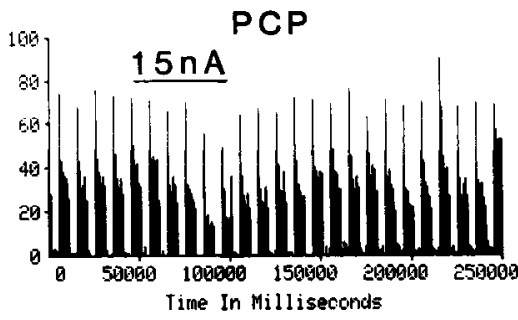

Figure 9. Effects of MKN and PCP on an STT cell. $A$, Location of the recording site, receptive field, and responses of the cell to graded intensities of mechanical stimulation. The histogram in $B$ shows the reduction by MKN ( $75 \mathrm{nA})$ of the responses of the cell to GLU pulses, while that in $D$ shows a comparable inhibition of the responses of the cell to a series of squeeze stimuli. PCP (7 and $15 \mathrm{nA}$ ) reduced the responses of the cell to GLU pulses $(C)$ and to squeeze stimuli $(E)$.
This was found in all 3 cells tested. Figure $9 E$ shows that PCP (15 nA) could produce an inhibition of the responses of this STT cell to repeated squeezing of the skin. PCP also inhibited the responses of 3 STT cells to volleys in A and C fibers evoked by electrical stimulation of a peripheral nerve.

MOR and PCP had similar effects on 5 STT cells. DYN and PCP could have similar effects, but, in some cases, DYN both inhibited and excited, while PCP inhibited a given STT cell. These 2 drugs were tested on 4 cells. MKN and PCP both inhibited 3 cells, although the strength and duration of the inhibitions differed.

NAM, another $\sigma$ receptor agonist, had effects that were similar to those of PCP. All 3 STT cells that were tested showed inhibition by NAM. Thresholds were between 7 and $25 \mathrm{nA}$. In 1 case, NAM produced inhibition, inhibition followed by excitation, or excitation alone, depending upon dose and electrode position. Figure 10 shows the inhibition of an STT cell (same cell shown in Fig. 7) by both NAM and PCP. In this case, NAM had a stronger inhibitory reaction than $\mathrm{PCP}$, and the inhibition by NAM was followed by facilitation. MOR also inhibited this cell.

NLX did not seem to antagonize the inhibitory effect of PCP in 3 of 4 cases. In the other case, there was an antagonism, and this recovered in $10 \mathrm{~min}$.

Both PCP and NAM could cause a reduction in and broadening of the anti- and orthodromic action potentials of STT cells. No tolerancelike effects to PCP were observed.

\section{Discussion}

The present study was designed to further our understanding of the mechanisms of opiate analgesia by examining the action of several opiate agonists applied iontophoretically onto cells of the primatc STT. Agonists of all of the opiate receptor subtypes tested $(\mu, \kappa, \delta, \sigma)$ had effects on these cells. The predominant action was inhibitory, confirming previous observations of opiate effects on dorsal horn nociceptive neurons (see reviews by Duggan and North, 1984; Zieglgänsberger, 1984) and our own study of the action of enkephalin on STT cells (Willcockson et al., 1984b).
However, we found that some agonists, especially MOR and DYN, could have an excitatory effect and that a given neuron could respond in different ways to a single drug, depending upon the position of the iontophoretic electrode array or on the iontophoretic current strength. Furthermore, 2 different opioids such as MOR and DYN, could have different actions when released at one position of the electrode array and similar actions at another. The simplest explanation of these multiple actions of opioid substances on STT cells is that several opiate receptor

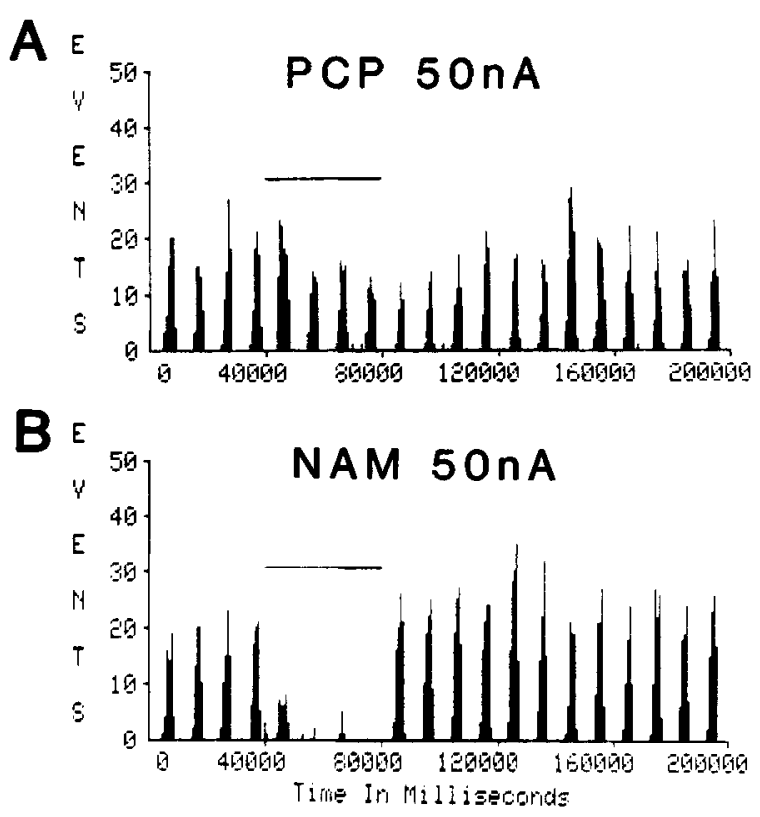

Figure 10. Inhibition of an STT cell by PCP $(A)$ and by NAM, or SKF $10047(B)$. The cell was the same as that illustrated in Figure 7. Iontophoretic application of either PCP $(50 \mathrm{nA})$ or NAM $(50 \mathrm{n} \Lambda)$ reduced the responses of the cell to GLU pulses. 
types are present on different parts of the dendritic tree of a given neuron ( $c f$. Zieglgänsberger et al., 1982) and that these may have either an inhibitory or an excitatory action, depending upon the opiate receptor type. The $\mu$ and $\kappa$ agonists (MOR, DYN) were the most likely to have excitatory actions, whereas $\delta$ (MKN) and $\sigma$ agonists (NAM, PCP) were almost always inhibitory.

Several alternative hypotheses have been used to explain the variable effects of opioid substances on dorsal horn neurons. These have included differential effects on non-nociceptive versus nociceptive cells (Belcher and Ryall, 1978; Calvillo et al., 1974, 1979; Einspahr and Piercey, 1980; Le Bars et al., 1975); contrary actions on cells lying in different laminae (Jurna and Grossman, 1976; Sastry and Goh, 1983; Woolf and Fitzgerald, 1981); control of nociceptive cells located deeper in the dorsal horn by opiate actions on dendrites or on other neurons located more superficially (Davies and Dray, 1978; Duggan et al., 1977a, b, 1981; Sastry and Goh, 1983; Woolf and Fitzgerald, 1981); blockade of receptors mediating excitatory or inhibitory actions of other neurotransmitters (Dostrovsky and Pomeranz, 1973, 1976); and toxic effects related to high concentrations of drugs emitted from iontophoretic electrodes (Piercey et al., 1980). We did not note any differences in opiate effects on STT cells at various depths in the dorsal horn, nor were there any obvious differences in the responses of LT, WDR, or HT STT cells. However, our sample size was not large enough to draw firm conclusions. Although we are attracted by the idea that the excitatory actions of opioids on some STT cells might be due to particular opiate receptors, we certainly cannot exclude the possibility that the release of an opioid substance caused the inhibition of a neighboring tonically active inhibitory interneuron (cf. Zieglgänsberger et al., 1979), resulting in a disinhibition. Another possibility is that DYN may sometimes act as an opiate antagonist (W. Zieglgänsberger, personal communication). This opens the possibility that DYN might reduce tonic opiate action and produce disinhibition in this way.

We presume that most of the effects we observed can be accounted for by a postsynaptic action of opioid substances, since we have relied heavily on changes in the responses of STT cells to GLU pulses to indicate an action of an iontophoretically applied drug (Zieglgänsberger and Bayerl, 1976; Zieglgänsberger and Puil, 1973; review by Zieglgänsberger, 1984). Opiate actions at postsynaptic sites have also been suggested by electrophysiologic (Barker et al., 1978; Dostrovsky and Pomeranz, 1973; Sutor and Zieglgänsberger, 1984; Zieglgänsberger and Bayerl, 1976; Zieglgänsberger and Tulloch, 1979) and immunocytochemical (Aronin et al., 1981; Hunt et al., 1980; Ruda et al., 1984) studies by others. Several different postsynaptic actions have been proposed, including a blocking action on chemically activated sodium channels (Barker et al., 1978, 1980; Zieglgänsberger and Bayerl, 1976; Zieglgänsberger and Tulloch, 1979), an increased potassium conductance (Yoshimura and North, 1983), and an increased chloride conductance (Barker et al., 1980). In addition, there is evidence for a presynaptic action of opioid substances (Aronin et al., 1981; Fields et al., 1980; Jessell and Iversen, 1977; LaMotte et al., 1976; MacDonald and Nelson, 1978; Mudge et al., 1979; Sastry, 1979). Besides these actions at the level of synapses on nociceptive neurons, there is a nonspecific "local anesthetic" action of opiates on the spikegenerating mechanism (e.g., Hu and Rubly, 1983; see review by Zieglgänsberger, 1984). This was presumably responsible for the reduction in height and broadening of the anti- and orthodromic spike potentials in STT cells when large iontophoretic currents were used to apply MOR, DYN, and other opioids in these experiments and in similar studies reported by others (Zieglgänsberger and Bayerl, 1976). Barker et al. (1980) report an elevated threshold for spike generation following enkephalin application to cultured neurons. This was presumably an opioidspecific effect because it could be prevented by naloxone.
Variations that were observed in opiate effects with repeated doses could sometimes be explained by prolonged actions or by reduced clearance of serially applied drugs, which could alter the effect of compounds applied later. For example, cumulative reductions of GLU-induced activity were sometimes noted with repeated applications of MOR or DYN. Qualitative differences in effect were nearly always associated with either a change in electrode position or in dose. There was little evidence for the development of tolerance.

In many of the experiments, an effort was made to test for the ability of locally applied NLX to prevent the effect of opioid substances applied iontophoretically onto STT cells. It was possible to demonstrate interference by NLX with the excitatory or inhibitory effects of MOR and MKN in some instances, although recovery from the NLX could not always be shown. NLX did not seem to have an antagonistic effect on the inhibition of 2 STT cells by DYN nor in most cases by PCP. In general, we found the use of iontophoretically applied NLX unsatisfactory for several reasons. The concentration of naloxone at the level of the opiate receptors is, of course, unknown and poorly controlled with this route of administration. This problem is exaggerated when agonists acting on a variety of opiate receptors having differing susceptibilities to NLX are being tested. Furthermore, when NLX was applied with a large iontophoretic current, the drug generally produced actions of its own, often of the same kind as produced by the opioid substance being tested ( $c f$. Gruol et al., 1980). The observations of others support the idea that the antagonistic effects of naloxone are probably better demonstrated by systemic than by iontophoretic administration (Calvillo et al., 1974, 1979; Davies and Dray, 1978).

It was interesting that the $\sigma$ receptor agonists, NAM and PCP, had strong inhibitory effects on STT cells when applied iontophoretically. Others have noted that NAM and PCP can inhibit dorsal horn interneurons (Anis et al., 1983; Berry et al., 1984), and $\sigma$ binding sites have been demonstrated in the spinal cord (Quirion ct al., 1981; Zukin and Zukin, 1979, 1981). NAM is a weak analgesic (Martin et al., 1976), but PCP and the related compound, ketamine, are anesthetics. Although the inhibitory effects of NAM and PCP on STT cells are likely to have been produced by an action on $\sigma$ opiate receptors, this is uncertain, since these agents also have pharmacological actions on other transmitter systems (Anis et al., 1983; Garvey and Heath, 1976; Johnson and Hillman, 1982; Smith et al., 1977; Taube et al., 1975; Vincent et al., 1978).

The results of this study are consistent with the suggestion that the different endogenous opioid substances found in the spinal cord may produce their effects through actions on different types of opiate receptors (Yaksh, 1981). However, proof of this awaits further testing with more specific agonists and antagonists.

\section{References}

Anderson, C. W., and M. R. Cushman (1981) A single and rapid method for making carbon fiber microelectrodes. J. Neurosci. Methods 4: 435-436.

Anis, N. A., S. C. Berry, N. R. Burton, and D. Lodge (1983) The dissociative anesthetic, ketamine and phencyclidine, selectively reduce excitation of central mammalian neurones by $\mathrm{N}$-methyl-aspartate. Br. J. Pharmacol. 79: 565-575.

Aronin, N., M. DiGiflia, A. S. Liotta, and J. B. Martin (1981) Ultrastructural localization and biochemical features of immunoreactive Leu-enkephalin in monkey dorsal horn. J. Neurosci. 1: 561-577.

Barker, J. L., T. G. Smith, and J. H. Neale (1978) Multiple membrane actions of enkephalin revealed using cultured spinal neurons. Brain Res. 154: 153-158.

Barker, J. L., D. L. Gruol, L. M. Huang, J. F. MacDonald, and T. G. 
Smith (1980) Peptide receptor functions on cultured spinal neurons. In Neural Peptides and Neuronal Communication, E. Costa and M. Trabucchi, eds., pp. 409-423, Raven, New York.

Belcher, G., and R. W. Ryall (1978) Differential excitatory and inhibitory effects of opiates on non-nociceptive and nociceptive neurones in the spinal cord of the cat. Brain Res. 145: 303-314.

Berry, S. C., S. L. Dawkins, and D. Lodge (1984) Comparison of $\sigma$ and $k$-opiate receptor ligands as excitatory amino acid antagonists. Br. J. Pharmacol. 83: 179-185.

Calvillo, O., J. L. Henry, and R. S. Ncuman (1974) Effects of morphine and naloxone on dorsal horn neurones in the cat. Can. J. Physiol. Pharmacol. 52: 1207-1211.

Calvillo, O., J. L. Henry, and R. S. Neuman (1979) Actions of narcotic analgesics and antagonists on spinal units responding to natural stimulation in the cat. Can. J. Physiol. Pharmacol. 57: 652-663.

Chang, K.-J., E. Hagum, and P. Cuatrecasas (1980) Possible role of distinct morphine and enkephalin receptors in mediating actions of benzomorphan drugs (putative $\kappa$ and $\sigma$ agonists). Proc. Natl. Acad. Sci. USA 77: 4469-4473.

Chavkin, C., I. F. James, and A. Goldstein (1982) Dynorphin is a specific endogenous ligand of the $x$ opioid receptor. Science 215:413415.

Chung, J. M., Z. R. Fang, C. L. Cargill, and W. D. Willis (1983) Prolonged naloxone-reversible inhibition of the flexion reflex in the cat. Pain 15: 35-53.

Chung, J. M., D. R. Kenshalo, Jr., K. D. Gerhart, and W. D. Willis (1979) Excitation of primate spinothalamic neurons by cutaneous C-fiber volleys. J. Neurophysiol. 42: 1354-1369.

Chung, J. M., K. H. Lee, Y. Hori, K. Endo, and W. D. Willis (1984) Factors influencing peripheral nerve stimulation produced inhibition of primate spinothalamic tract cells. Pain 19: 277-293.

Curtis, D. R. (1964) Microelectrophoresis. In Physical Techniques in Biological Research, Vol. 5, Pt. A, W. L. Nastuk, ed., pp. 144-190, Academic, New York.

Davies, J., and A. Dray (1978) Pharmacological and electrophysiological studies of morphine and enkephalin on rat supraspinal neurones and cat spinal neurones. Br. J. Pharmacol. 63: 87-96.

Dostrovsky, J., and B. Pomeranz (1973) Morphine blockade of amino acid putative transmitters on cat spinal cord sensory interneurones. Nature [New Biol.] 246: 222-224.

Dostrovsky, J., and B. Pomeranz (1976) Interaction of iontophoretically applied morphine with responses of interneurons in cat spinal cord. Exp. Neurol. 52: 325-338.

Duggan, A. W., and R. A. North (1984) Electrophysiology of opioids. Pharmacol. Rev. 35: 219-281.

Duggan, A. W., J. Davies, and J. G. Hall (1976) Effects of opiate agonists and antagonists on central neurons of the cat. J. Pharmacol. Exp. Ther. 196: 107-120.

Duggan, A. W., J. G. Hall, and P. M. Headley (1977a) Suppression of transmission of nociceptive impulses by morphine: Selective effects of morphine administered in the region of the substantia gelatinosa. Br. J. Pharmacol. 61: 65-76.

Duggan, A. W., J. G. Hall, and P. M. Headley (1977b) Enkephalin and dorsal horn neurones of the cat: Effects on responses to noxious and innocuous skin stimuli. Br. J. Pharmacol. 61: 399-408.

Duggan, A. W., S. M. Johnson, and C. R. Morton (1981) Differing distributions of receptors for morphine and met-5-enkephalinamide in the dorsal horn of the cat. Brain Res. 229: 379-387.

Einspahr, F. J., and M. F. Piercey (1980) Morphine depresses dorsal horn neuron responses to controlled noxious and non-noxious cutaneous stimulation. J. Pharmacol. Exp. Ther. 213: 456-461.

Fields, H. L., P. C. Emson, B. K. Leigh, R. F. T. Gilbert, and L. L. Iversen (1980) Multiple opiate receptor sites on primary afferent fibres. Nature 284: 351-353.

Garvey, R. E., and R. G. Heath (1976) The effects of phencyclidine on the uptake of ${ }^{3} \mathrm{H}$-catecholamine by rat striatal and hypothalamic synaptosomes. Life Sci. 18: 1105-1110.

Gerhart, K. D., T. K. Wilcox, J. M. Chung, and W. D. Willis (1981) Inhibition of nociceptive and nonnociceptive responses of primate spinothalamic cells by stimulation in medial brain stem. J. Neurophysiol. 45: 121-136.

Gerhart, K. D., R. P. Yezierski, T. K. Wilcox, and W. D. Willis (1984) Inhibition of primate spinothalamic tract neurons by stimulation in periaqueductal gray or adjacent midbrain reticular formation. J. Neurophysiol. 51: $450-466$.
Gruol, D. L., J. L. Barker, and T. G. Smith (1980) Naloxone antagonism of GABA-evoked membrane polarizations in cultured mouse spinal cord neurons. Brain Res. 198: 323-332.

$\mathrm{Hu}, \mathrm{S}$., and N. Rubly (1983) Effects of morphine on ionic currents in frog node of Ranvier. Eur. J. Pharmacol. 95: 185-192.

Huidoboro-Toro, J. P., K. Yoshimura, N. M. Lee, H. L. Loh, and E. L. Way (1981) Dynorphin interaction at the $k$-opiate site. Eur. J. Pharmacol. 72: 265-266.

Hunt, S. P., J. S. Kelly, and P. C. Emson (1980) The electron microscopic localization of methionine-enkephalin within the superficial layers (I and II) of the spinal cord. Neuroscience 5: 1871-1890.

Hutchinson, M., H. W. Kosterlitz, F. M. Leslie, A. A. Waterfield, and L. Terenius (1975) Assessment in the guinea-pig ileum and mouse vas deferens of benzomorphans which have strong antinociceptive activity but do not substitute for morphine in the dependent monkey. Br. J. Pharmacol. 55: 541-546.

Jessell, T. M., and L. L. Iversen (1977) Opiate analgesics inhibit substance $P$ release from rat trigeminal nucleus. Nature 268: 549-551.

Johnson, K. M., and G. R. Hillman (1982) Comparisons between phencyclidine and its monohydroxylated metabolites, and the stereoisomers of N-allyl-N-normetazocine (SKF 10047) as inhibitors of the muscarinic receptor in acetylcholinesterase. J. Pharm. Pharmacol. 34: 462-464.

Jordan, L. M., D. R. Kenshalo, R. F. Martin, L. H. Haber, and W. D. Willis (1978) Depression of primate spinothalamic tract neurons by iontophoretic application of 5-hydroxytryptamine. Pain 5: 135-142.

Jurna, I., and W. Grossman (1976) The effect of morphine on the activity evoked in ventrolateral tract axons of the cat spinal cord. Exp. Brain Res. 24: 473-484.

Kitahata, L. M., Y. Kosaka, A. Taub, K. Bonikos, and M. Hoffert (1974) Lamina-specific suppression of dorsal-horn unit activity by morphine sulfate. Anesthesiology 41: 39-48.

Kosterlitz, H. W., J. A. H. Lord, S. J. Paterson, and A. A. Waterfield (1980) Effects of changes in the structure of enkephalins and of narcotic analgesic drugs on their interactions with $\mu$ and $\delta$ receptors. $\mathrm{Br}$. J. Pharmacol. 68: 333-342.

LaMotte, C., C. B. Pert, and S. H. Snyder (1976) Opiate receptor binding in primate spinal cord: Distribution and changes after dorsal root section. Brain Res. 112: 407-412.

Le Bars, D., G. Guilbaud, I. Jurna, and J. M. Besson (1976) Differential effects of morphine on responses of dorsal horn lamina $V$ type cells elicited by $A$ and $C$ fibre stimulation in the spinal cat. Brain Res. 115: 518-524.

Le Bars, D., D. Menetrey, C. Counseiller, and J. M. Besson (1975) Depressive effects of morphine upon lamina $V$ cell activities in the dorsal horn of the spinal cat. Brain Res. 98: 261-277.

Lord, J. A. H., A. A. Waterfield, J. Hughes, and H. W. Kosterlitz (1977) Endogenous opioid peptides: Multiple agonists and receptors. Nature 267: 495-499.

MacDonald, R. L., and P. G. Nelson (1978) Specific opiate-induced depression of transmitter release from dorsal root ganglion cells in culture. Science 199: 1449-1451.

Martin, W. R. (1984) Pharmacology of opioids. Pharmacol. Rev. 35: 283-323.

Martin, W. R., C. G. Eades, J. A. Thompson, R. E. Hippler, and P. E. Gilbert (1976) The effects of morphine and nalorphine-like drugs in the nondependent and morphine-dependent chronic spinal dog. $J$. Pharmacol. Exp. Ther. 197: 517-532.

Mudge, A. W., S. T. Leeman, and G. D. Fischbach (1979) Enkephalin inhibits release of substance $P$ from sensory neurons in culture and decreases action potential duration. Proc. Natl. Acad. Sci. USA 76: 526-530.

Noordenbos, W., and P. D. Wall (1976) Diverse sensory function with an almost totally divided spinal cord. A case of spinal cord transection with preservation of part of one anterolateral quadrant. Pain 2: 185195.

North, R. A. (1979) Opiates, opioid peptides and single neurones. Life Sci. 24: 1527-1546.

Olszewski, J. (1952) The Thalamus of Macaca mulatta. Karger, New York.

Piercey, M. F., F. J. Einspahr, P. J. K. Dobry, L. A. Schroeder, and R P. Hollister (1980) Morphine does not antagonize the substance $P$ mediated excitation of dorsal horn neurons. Brain Res. 186: 421434.

Quirion, R., R. P. Hammer, Jr., M. Herkenham, and C. B. Pert (1981) 
Phencyclidine (angel dust)/"opiate" receptor: Visualization by tritium sensitive film. Proc. Natl. Acad. Sci. USA 78: 5881-5885.

Randić, M., and V. Miletić (1978) Depressant actions of methionineenkephalin and somatostatin in cat dorsal horn neurones activated by noxious stimuli. Brain Res. 152: 196-202.

Ruda, M. A., J. Coffield, and R. Dubner (1984) Demonstration of postsynaptic opioid modulation of thalamic projection neurons by the combined techniques of retrograde horseradish peroxidase and enkephalin immunocytochemistry. J. Neurosci. 4: 2117-2132.

Sastry, B. R. (1979) Presynaptic effects of morphine and methionineenkephalin in feline spinal cord. Neuropharmacology 18: 367-375.

Sastry, B. R., and J. W. Goh (1983) Action of morphine and metenkephalinamide on nociceptor driven neurones in substantia gelatinosa and deeper dorsal horn. Neuropharmacology 22: 119-122.

Satoh, M., S. I. Kawajili, Y. Ukai, and M. Mamamoto (1979) Selective and nonselective inhibition by enkephalin and noradrenaline of nociceptive response of lamina $\mathrm{V}$ type neurons in the spinal dorsal horn of the rabbit. Brain Res. 177: 384-387.

Smith, R. C., H. Y. Meltzer, R. C. Arora, and J. M. David (1977) Effects of phencyclidine on $\left[{ }^{3} \mathrm{H}\right]$-catecholamine and $\left[{ }^{3} \mathrm{H}\right]$-serotonin uptake in synaptosomal preparation from rat brain. Biochem. Pharmacol. 26: 1435-1439.

Sutor, B., and W. Zieglgänsberger (1984) Actions of D-ala ${ }^{2}-\mathrm{D}-\mathrm{leu}^{5}-$ enkephalin and dynorphine $\mathrm{A}(1-17)$ on neocortical neurons in vitro. Neuropeptides 5: 241-244.

Taube, H. D., H. Montel, G. Hau, and K. Starke (1975) Phencyclidine and ketamine: Comparison with the effect of cocaine on the noradrenergic neurones of the rat brain cortex. Naunyn Schmiedebergs Arch. Pharmacol. 291: 47-54.

Trevino, D. L., J. D. Coulter, and W. D. Willis (1973) Location of cells of origin of spinothalamic tract in lumbar enlargement of the monkey. J. Neurophysiol. 36: 750-761.

Vierck, C. J., and M. M. Luck (1979) Loss and recovery of reactivity to noxious stimuli in monkeys with primary spinothalamic cordotomies, followed by secondary and tertiary lesions of other cord sectors. Brain Res. 102: 233-248.

Vincent, J. P., D. Carey, J. M. Kamenka, P. Geneste, and M. Logdunski (1978) Interaction of phencyclidine with the muscarinic and opiate receptors in the central nervous system. Brain Res. 152: 176-182.

Willcockson, W. S., J. M. Chung, Y. Hori, K. H. Lee, and W. D. Willis (1984a) Effects of iontophoretically released amino acids and amines on primate spinothalamic tract cells. J. Neurosci. 4: 732-740.

Willcockson, W. S., J. M. Chung, Y. Hori, K. H. Lee, and W. D. Willis (1984b) Effects of iontophoretically released peptides on primate spinothalamic tract cells. J. Neurosci. 4: 741-750.

Willcockson, W. S., J. Kim, H. K. Shin, J. M. Chung, and W. D. Willis (1985) Responses of spinothalamic tract cells to opiates affecting different receptor subclasses. Abstr. Soc. Neurosci. 11: 1177.

Willis, W. D. (1982) Control of nociceptive transmission in the spinal cord. In Progress in Sensory Physiology, D. Ottoson, ed., pp. 1-159, Springer-Verlag, Berlin.
Willis, W. D. (1985) The pain system. In Pain and Headache, Vol. 8, P. L. Gildenberg, ed., pp. 1-346, Karger, Basel.

Willis, W. D., L. H. Haber, and R. F. Martin (1977) Inhibition of spinothalamic tract cells and interneurons by brain stem stimulation in the monkey. J. Neurophysiol. 40F: 968-981.

Willis, W. D., D. L. Trevino, J. D. Coulter, and R. A. Maunz (1974) Responses of primate spinothalamic tract neurons to natural stimulation of hindlimb. J. Neurophysiol. 37: 358-372.

Woolf, C. J., and M. Fitzgerald (1981) Lamina-specific alteration of C-fibre evoked activity hy morphine in the dorsal horn of the rat spinal cord. Neurosci. Lett. 25: 37-41.

Woolf, C. J., D. Mitchell, and G. D. Barrett (1980) Antinociceptive effect of peripheral segmental electrical stimulation in the rat. Pain 8: $237-252$.

Wüster, M., R. Schulz, and A. Herz (1980) The direction of opioid agonists towards $\mu$-, $\delta$ - and $k$-receptors in the vas deferens of the mouse and the rat. Life Sci. 27: 163-170.

Yaksh, T. L. (1981) Spinal opiate analgesia: Characteristics and principles of action. Pain 11: 293-346.

Yaksh, T. L., and R. P. Elde (1981) Factors governing release of methionine enkephalin-like immunoreactivity from mesencephalon and spinal cord of the cat in vivo. J. Neurophysiol. 46: 1056-1075.

Yoshimura, M., and R. A. North (1983) Substantia gelatinosa neurones hyperpolarized in vitro by enkephalin. Nature 305: 529-530.

Zieglgänsberger, W. (1984) Opioid actions on mammalian spinal neurons. Int. Rev. Neurobiol. 25: 243-275.

Zieglgänsberger, W., and H. Bayerl (1976) The mechanism of inhibition of neuronal activity by opiates in the spinal cord of the cat. Brain Res. 115: 111-128.

Zieglgänsberger, W., and E. A. Puil (1973) Actions of glutamic acid on spinal neurones. Exp. Brain Res. 17: 35-49.

Zieglgänsberger, W., and B. Sutor (1983) Responses of substantia gelatinosa neurons to putative neurotransmitters in an in vitro preparation of the adult rat spinal cord. Brain Res. 279: 316-320.

Zieglgänsberger, W., and I. F. Tulloch (1979) The effects of methionine- and leucine-enkephalin on spinal neurones of the cat. Brain Res. 167: 53-64.

Zieglgänsberger, W., E. D. French, G. R. Siggins, and F. E. Bloom (1979) Opioid peptides may excite hippocampal pyramidal neurons by inhibiting adjacent inhibitory interneurons. Science 205: 415-417.

Zieglgänsberger, W., E. D. French, N. Mercuri, F. Pelayo, and J. T. Williams (1982) Multiple opiate receptors on neurons of the mammalian central nervous system. In vivo and in vitro studies. Life Sci. 31: $2343-2346$.

Zukin, R. S., and S. R. Zukin (1981) Demonstration of $\left[{ }^{3} \mathrm{H}\right]$ cyclazocine binding to multiple opiate receptor sites. Mol. Pharmacol. 20:246254.

Zukin, S. R., and R. S. Zukin (1979) Specific [ $\left.{ }^{3} \mathrm{H}\right]$ phencyclidine binding in rat central nervous system. Proc. Natl. Acad. Sci. USA 76: $5372-5376$ 